\title{
Technical review on jet fuel production
}

\author{
Guangrui Liu ${ }^{\mathrm{a}, \mathrm{b}, *}$, Beibei Yan ${ }^{\mathrm{b}}$, Guanyi Chen ${ }^{\mathrm{b}, *}$ \\ a Qingdao Institute of Bioenergy and Bioprocess Technology, Chinese Academy of Sciences, Qingdao 266101, China \\ b School of Environment Science and Engineering/State Key Laboratory of Engines, Tianjin University, Tianjin 300072, China
}

\section{A R T I C L E I N F O}

\section{Article history:}

Received 23 September 2011

Received in revised form 5 March 2013

Accepted 15 March 2013

Available online 14 May 2013

Keywords:

Jet fuel

Production process

Synthetic paraffinic kerosene

Fischer-Tropsch synthesis

Biofuel

\begin{abstract}
A B S T R A C T
In present study, we investigated jet fuel production process, including the crude oil-based conventional process, unconventional oil sources-based process, Fischer-Tropsch synthesis (F-T) process and renewable jet fuel process and analyzed the details of each jet fuel production process. Among these jet fuel production technologies, the F-T synthesis and renewable jet fuel process supply alternative fuels with potential environmental benefit of reduced life cycle greenhouse gas (GHG) emissions and the economic benefits associated with increased fuel availability and lower fuel costs. The F-T synthesis has a major advantage with the possibility of accepting any carbon-based input, which makes it suitable for using a variety of sources such as coal, natural gas and 2nd generation biomass as feedstocks. The renewable jet fuel process such as Bio-Synfining ${ }^{\mathrm{TM}}$ (Syntroleum) and Ecofining ${ }^{\mathrm{TM}}$ (UOP) as well as C-L $\mathrm{L}^{\mathrm{TM}}$ (Tianjin University) is a low capital cost process of producing high quality synthetic paraffinic kerosene (SPK) from bio-renewable feeds like vegetable oils/fats and waste cooking oils/fats, greases, energy plants of jatropha and algal. The SPK has superior fuel properties to other options available today, with higher cetane number, lower cloud point and lower emissions
\end{abstract}

(c) 2013 Published by Elsevier Ltd.

\section{Contents}

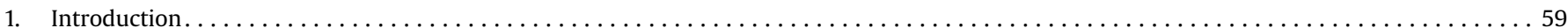

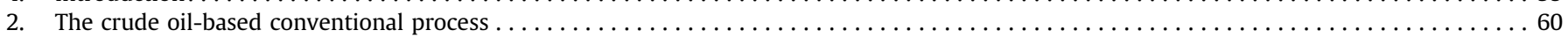

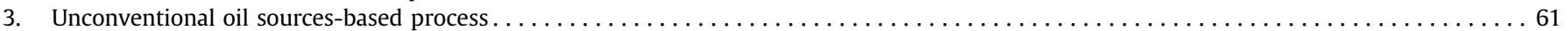

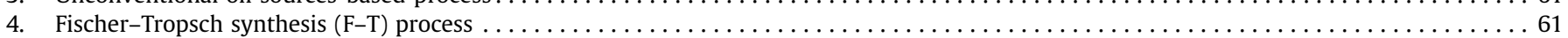

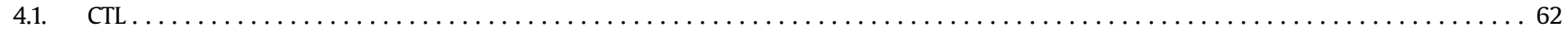

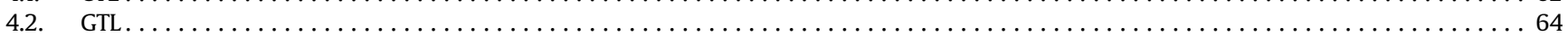

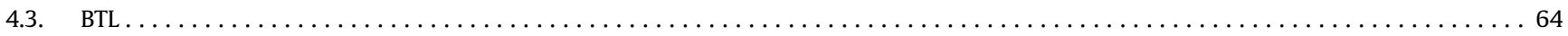

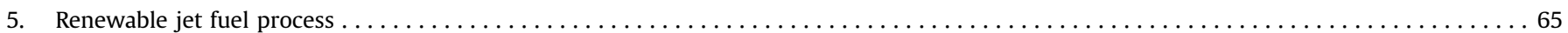

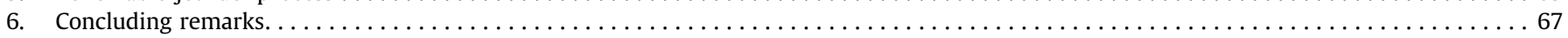

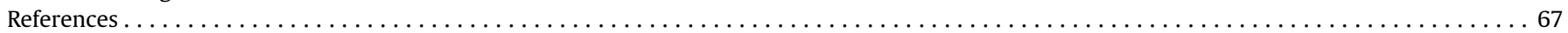

\section{Introduction}

The world is changing and so is the aviation industry [1-4]. Now with declining petroleum resources and shocking surge in the price of fuel, combined with the increase in political and environmental concern and the current economic downturn, it is imperative to develop renewably clean and energy-efficient technologies for producing sustainable products of fuels [2,5-7].

\footnotetext{
* Corresponding authors. Tel.: +86 228740 1929; fax: +8622 87402075

E-mail addresses: grliu@tju.edu.cn (G. Liu), chen@tju.edu.cn (G. Chen).
}

Aviation is powered by liquid petroleum fuel especially liquid jet fuel, which requires higher energy contents per unit volume than gases, and is easier to handle and distribute than solids [8-10]. The consumption of jet fuel has been declining from 191.1 million gallons per day in 2000 to 189.1 million gallons per day in 2001, growing up to 198.3 million gallons per day in 2008 . However, the United States is the largest single market around the world, consuming about $37 \%$ of the worldwide total [11]. Statistically, fuel has represented about $10-15 \%$ of airline operating cost. The large fluctuation in the cost of fuel has promoted a strong incentive for airlines to shift to use of alternative sources of fuel. According to previous studies, the fatty acid methyl esters (FAME), 
synthetic alcohols (bio-ethanol or bio-methanol), synthetic hydrocarbons from sugars, dimethyl ether (DME) and hydrogen could be possibly used as aviation gas turbine alternative fuels. However, the high quality requirements for the commercial aviation fuels strictly limit the wide application of these alternative fuels for all exiting aircrafts $[12,13]$.

According to the International Energy Agency (IEA), transportation system contributes about $23 \%$ of energy-related carbon dioxide emissions $\left(\mathrm{CO}_{2}\right)$ all over the world, and this share will likely rise in the future [14]. Aviation contributes approximately $2 \sim 3 \%$ of the world's anthropogenic carbon dioxide emissions, but has received considerable attention regarding these emissions [15-17]. In 2007, the European Parliament voted to bring aviation into the European GHG-emission trading system (EU-ETS) $[18,19]$. This legislation would require all airlines flying within or into Europe region decrease their GHG emissions by $10 \%$ or buy $\mathrm{CO}_{2}$ allowances on the open market after it takes effect in 2012 [20-22]. The aviation industry is facing billions of dollars of cost increase from their prospective, requiring carbon credit purchases via their entry into the EU's emissions trading scheme [6,23,24]. In order to deal with this issue, aviation industries have explored several improvements on engine \& airframe technology, operation \& fleet management and other measures [19,22,24-28]. Moreover, alternative fuel is an imminent part of the aviation industry's future $[15,29]$. Renewable jet fuels could significantly lower GHG emissions and provide a long-term sustainable alternative to petroleum jet fuel $[30,31]$. Following the first successful biofuel flight of a Virgin Atlantic Airways 747-400, more commercial airlines conducted successful in-flight tests using sustainable alternative jet fuel. The fuel was produced from second generation of biomass sources, including camelina, jatropha and algae, reducing the fuel's carbon footprint by $80 \%$ relative to jet fuel without competing for resources with food production [32].

The most widely used quality standards of conventional petroleum-derived jet fuel are the ASTM D1655 (US) and DEF STAN 91/91 (UK Ministry of Defence). A number of other specifications also exist, such as DCSEA (France) and GHOST (Russia). The specification of aviation kerosene has changed and developed in line with safety and security of supply criteria [11,33,34]. In December 2007, DEF STAN 91/91 approved 100\% Sasol fullsynthetic fuel, which represented the world's first fully synthetic jet fuel approved for use in all commercial and military engines [35]. Besides, The American Society for Testing and Materials (ASTM) created a new specification ASTM D7566 for blends containing synthetic jet fuel. This new specification entitled as "Standard Specification for Aviation Turbine Fuel Containing Synthesized Hydrocarbons". This specification certifies a 50\% blend of Jet-A and synthetic paraffinic kerosene (SPK) produced from biomass using an alternative process. It also provides a framework for certifying new alternative fuels as they are developed.

Aviation liquid fuels would be derived from different materials by different methods [36]. In the present study, we investigated four different typical jet fuel production technologies, which include the conventional process from crude oil, the route from unconventional oil sources, the Fischer-Tropsch synthesis (F-T) and the renewable jet fuel process. Besides, the details of each jet fuel producing technology were analyzed and the comparison between each other was made.

\section{The crude oil-based conventional process}

The discovery of crude oil created an inexpensive liquid fuel source that helped industrialize the world and improve living standards, while the fossil fuels have contributed to over $80 \%$ of energy expenses. Crude oil, also called petroleum, is a complex mixture of hydrocarbons. The carbon and hydrogen in crude oil are thought to have originated from the remains of microscopic marine organisms that were deposited at the bottom of seas and oceans and were transformed at high temperature and pressure into crude oil. Global oil production is approximately 81.5 million barrels per day, which is equivalent to an annual output of 3905.9 million tonnes in 2008 [37]. The International Energy Agency (IEA) has estimated that the world's total refinery production in 2006 is 3861 million tonnes. The aviation fuel accounts for $6.3 \%$ of the total amount of oil consumed. Petroleum refining is a process of separating many compounds present in crude petroleum [38]. This process is called atmospheric \& vacuum fractional distillation where the crude oil is heated and compounds boil at different temperatures and change to gases. These gases are later recondensed back into liquids [39]. Fig. 1 shows the basic flow sheet of atmospheric fractional distillation.

The lowest boiling fraction, taken from the top of the distillation column, is called naphtha. It is mainly processed further to make motor gasoline. The second fraction of about 33\% of the crude oil input contains the raw material for jet fuel production. This fraction is further processed in the distillate hydrotreater to become kerosene and special solvents, followed by the so-called "gas oil" or "middle distillate base oil" fraction which includes diesel fuel and heating oil. Basically, kerosene is originated as a straight-run (distilled) petroleum fraction with boiling temperature ranging from $205^{\circ} \mathrm{C}$ to $260{ }^{\circ} \mathrm{C}$. If jet fuel production was to increase, obviously the production of other products would decrease [40]. Finally, although the bottoms fractions or residual fraction can be used as heavy boiler fuel, it is usually vacuum distilled first to yield more high-value distillate [41].

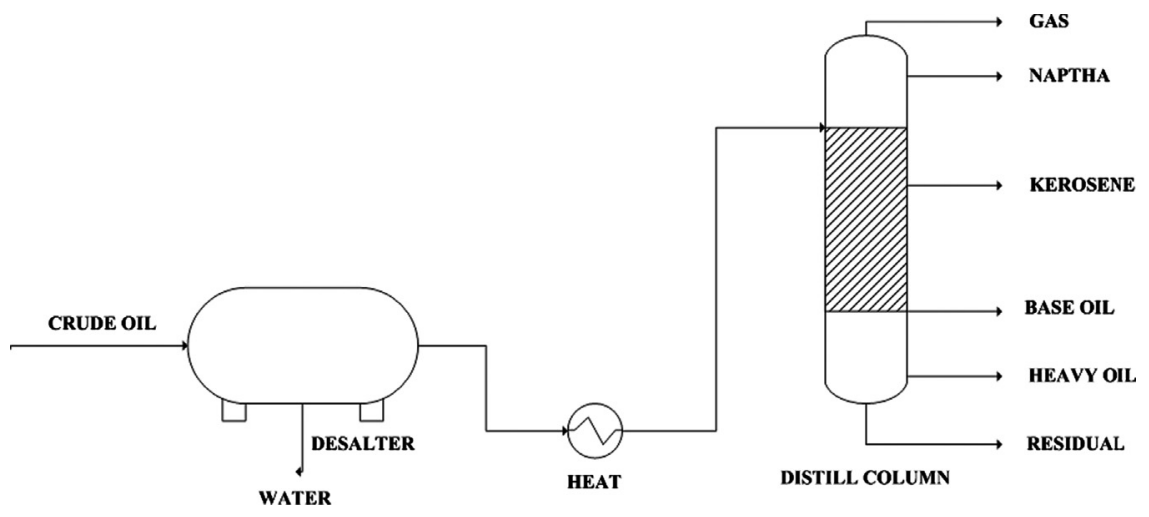

Fig. 1. The conventional route for jet fuel production from crude oil. 
Jet fuel derived from crude petroleum oil has a wide distribution of paraffins. A typical jet composition can be described as $20 \%$ normal paraffins, $40 \%$ isoparaffins, $20 \%$ naphthenes, and $20 \%$ aromatics [42]. While the specifications for Jet $A$ set a maximum limit on total aromatic content of $25 \%$, which could reduce the hydrogen to carbon ratio and the heat content per unit mass compared to paraffins with the same carbon number $[29,43]$. However, the seals in the aircraft and engine would leak if the aromatic content was too low.

\section{Unconventional oil sources-based process}

Almost all jet fuel of today is manufactured from crude oil. A relatively small percentage is made from three unconventional sources of petroleum-Canadian oil sands, Venezuelan VHOs, and oil shale [44-47]. Oil sands are deposits of bitumen in sand or porous rock. Bitumen is a mixture of hydrocarbons that has very high viscosity and is difficult to flow $[48,49]$. The world's largest source of oil sands is located in the province of Alberta, Canada. The Alberta oil sand deposits contain about 1.6 trillion barrels of oil, which cover an area of approximately $40,000 \mathrm{~km}^{2}$. Among these, about 300 billion barrels oil sands are estimated to be recoverable using current open pit mining and in-situ technologies [50]. Venezuela's VHOs are similar in chemical and physical characteristics to Canadian bitumen with a heavier density than water. Both of them have higher concentrations of oxygen, nitrogen, and sulfur than light crude oil. Venezuela holds an estimated 1.2 trillion barrels of VHO resources, of which an estimated 200 billion barrels would be easy to recover via surface mining or in-situ extraction. Surface mining is usually limited to oil-sand deposits that are relatively close to the surface. After being physically separated from the sands, the bitumen is transported to a central facility for upgrading. In in-situ extraction, steam is pumped into the oil-sand deposit and VHOs to reduce the viscosity of the bitumen. Afterwards it can flow to wells and be recovered in the same manner as conventional petroleum.

There are several patented processes for the separation of bitumen from oil sands. All of them are based on solvent extraction and mainly by water [51]. First, the oil sand is extracted with hot water to remove most of the sand and clay. Then the froth is diluted with a light hydrocarbon, the water and solids quickly settle to leave diluted bitumen with traces of water and solids to float. This process separates most of the bitumen in the tar sand and produces a product with fairly low solids content [52]. However, water pollution was reported to represent a serious environmental concern. In addition, because of the consolidated nature of the deposits and the high viscosity of the bitumen, the application of this method has not been commercially successful [53]. In order to deal with these challenges, some researchers released $90 \%$ bitumen from oil sands by the method of employing ionic liquids together with a nonpolar solvent at ambient temperatures [54]. The upgraded bitumen also could be produced from Alberta tar sands by vacuum pyrolysis [55]. The oil yield was $10.8 \%$ by weight under the reaction conditions of $500{ }^{\circ} \mathrm{C}$ and a total pressure of $1 \mathrm{kPa}$. Moreover, the major pyrolysis gases like $\mathrm{CO}_{2}$ (the most abundant), $\mathrm{CO}, \mathrm{H}_{2} \mathrm{~S}$, and $\mathrm{CH}_{4}$, and $\mathrm{C}_{2}-\mathrm{C}_{8}$ hydrocarbons were also produced during pyrolysis.

Oil shale is a solid sedimentary rock containing an insoluble organic matter called kerogen, which can be decomposed by pyrolysis to form desired oil that can be distilled like conventional petroleum. Kerogen is a complex substance consisting of large molecules of carbon and hydrogen with nitrogen, sulfur and oxygen atoms and an approximate empirical formula would be $\mathrm{C}_{200} \mathrm{H}_{300} \mathrm{SN}_{5} \mathrm{O}_{11}$. The oil shale resource in the United States is very large and highly concentrated in the parts of Colorado, Utah, and
Wyoming and the recoverable resources range from 500 billion to 1.1 trillion barrels. Besides, Spain has moderate deposits of oil shale and it is the only organic natural resource for producing energy in Israel $[56,57]$. Due to the work performed by the U.S. Department of Defense (DoD) in the 1980s, shale oil has been included in the specification for Jet $A$ as a conventional source of jet fuel that would be fully compatible with current aviation systems.

Pyrolysis has been used to extract kerogen from oil shales $[58,59]$. This process requires the treatment of large amounts of solid material, including a method for grinding the rocks down to a suitable particle size. This technology is involved in mining the shale, separating the shale oil using a high temperature retorting process and finally upgrading the shale oil to fuels by hydroprocess. Oil-shale production requires significant energy inputs and the maximum oil yield depends on the properties of the oil shale, heating rate, and particle grain size by pyrolysis $[56,57,60]$. The new technology based on the use of water, toluene and methanol as solvents under supercritical conditions, is still under development, and their technical and economical viability have not yet been validated [61-63]. However, some advantages were reported such as better selectivity, a more efficient energy balance and better extraction capacity with supercritical technology [61,64-66]. Considering the technical maturity of oil shale production methods, oil shale is unlikely to support appreciable production of jet fuel prior to 2020 [67].

Jet fuel produced from these three unconventional oils currently could meet all specifications for Jet A. However, they have the largest potential for only supplying several-thousand barrels jet fuel per day. Therefore, they received a neutral rating for compatibility. Moreover, their use would result in increasing GHG emissions [68]. The use of Jet A derived from oil sands and VHOs would have life-cycle GHG emissions ranging from $10 \%$ to $25 \%$ greater in life-cycle than conventional crude oil, and use of oil-shale fuel by $50 \%$ higher than conventional crude oil. Once the fuel reaches the tank, there are no differences in emissions or effect on air quality.

\section{Fischer-Tropsch synthesis (F-T) process}

Fischer-Tropsch (F-T) is often regarded as the key technological component for converting synthesis gas (or "syngas") to transportation fuels and other liquid products [69]. German researchers Franz Fischer and Hans Tropsch developed this method bearing their names in 1922 as a method for making liquid fuels from coal with alkalized iron chips at $673 \mathrm{~K}$ and under high pressure ( $>100$ bar) [70]. The F-T process appears to be on the verge of a period of expansion. Several major companies have announced plans to build large plants. If completed, these projects would yield about 1 million barrels per day of total product by 2020 , some of which could potentially be used as aviation fuel. F-T fuels have several characteristics that make them attractive as a jet fuel $[71,72]$. Their higher specific energy leads to a small reduction in the amount of energy required to fly a given distance with a given payload and could allow for increased payload capacity [73]. $\mathrm{F}-\mathrm{T}$ fuels are clean burning without sulfur dioxide $\left(\mathrm{SO}_{2}\right)$ or sulfuric acid $\left(\mathrm{H}_{2} \mathrm{SO}_{4}\right)$ aerosol emissions, thus leading to increased combustor and turbine life, and meanwhile their improved thermal stability should reduce deposits on engine components and fuel lines $[74,75]$. Furthermore, this aromatic-free fuel emits fewer particulates than conventional jet fuel. However, there are two disadvantages associated with no aromatics in the fuel. First, F-T kerosene meets all other jet fuel specification properties with an exception of the minimum density requirement. Second, the absence of aromatic compounds can cause leaks in certain types 
of fuel system. Both of these issues may be resolved by blending the fuel with conventional jet fuel and may be addressed with the appropriate use of fuel additives.

After several decades of research and development, F-T technology has finally come to the stage of full-scale industry and worldwide commercialization. There has been extensive evaluation of synthetic paraffinic kerosene (SPK) produced from a starting material of coal using the Fischer-Tropsch process. A leader in developing and commercializing this technology is Sasol located in Johannesburg, South Africa, and the Sasol FT-SPK jet fuel is approved for use in commercial aviation. Since 1999, blends that are up to $50 \% \mathrm{~F}-\mathrm{T}$ liquids have been used by commercial airlines in South Africa. The FT-SPK fuels were composed of a combination of normal and iso-paraffins with a small percentage of cyclo-paraffins. The paraffins carbon number and type (iso- and $n$-) of the neat FT-SPKs varies from $C_{9}$ to $C_{15}$ which is a typical range found in conventional jet fuel.

The F-T process has four main steps. The first step is the production of synthesis gas, which is a mixture of hydrogen and carbon monoxide. The second main step removes undesired compounds such as $\mathrm{CO}_{2}$ as well as impurities from the synthesis-gas stream. The third step is the F-T synthesis. This process makes mainly straight chain hydrocarbons. The product composition will vary depending on the hydrogen to carbon monoxide ratio, the catalyst and process conditions. This raw product (straight chain hydrocarbons) of F-T synthesis must be further processed to make an acceptable fuel. After leaving the F-T section of the facility, the hydrocarbon product is upgraded to liquid fuels using wellestablished methods in common petroleum refineries. This processing includes cracking the long chains into smaller units and rearranging some of the atoms (isomerizing) to provide the desired properties. The outputs of the process can be narrowed to middle distillates and naphtha, both of which have a near-zero level of sulfur.

According to the temperature applied, the F-T process would be divided into low-temperature F-T process (LTFT) and hightemperature $\mathrm{F}-\mathrm{T}$ process (HTFT), whereby LTFT ranges between 200 and $240{ }^{\circ} \mathrm{C}$ and HTFT ranges between 300 and $350{ }^{\circ} \mathrm{C}[76,77]$. The low-temperature F-T process with either iron or cobalt catalyst is used for the production of high molecular mass linear waxes [78-80]. The high-temperature F-T process with iron-based catalyst is used for the production of gasoline and linear low molecular mass olefins. However, the main difference is that no liquid phase is present outside the catalyst particles in the HTFT reactors [81].

The $\mathrm{F}-\mathrm{T}$ reaction with $\mathrm{Fe}$ and $\mathrm{Co}$ as viable catalysts is highly exothermic, which is a significant characteristic, thus influencing the efficiency of the whole process $[82,83]$. Cobalt-based F-T catalysts are usually preferred for the synthesis of long-chain paraffins, as they are more stable towards deactivation by water [73]. Furthermore, when iron is used as catalyst, the F-T occurs simultaneously with the water-gas shift (WGS) reaction, which consumes $\mathrm{CO}$ and $\mathrm{H}_{2} \mathrm{O}$ obtained from the $\mathrm{F}-\mathrm{T}$ and produces additional $\mathrm{H}_{2}$ and $\mathrm{CO}_{2}$. The iron catalysts are preferred to $\mathrm{Co}$ catalysts, due to its lower cost, lower methane selectivity, lower sensitivity to poisons, and higher flexibility to lead the selectivity to required products according to the operative variables used and calcination conditions on the catalytic performance [78,84]. The kinetic process can be expressed by the equations in Fig. 2 $[70,85,86]$. Here " $n$ " is the average carbon number and " $m$ " is the average number of hydrogen atoms of the hydrocarbon products. Eqs. (a) and (b) are the main reactions for the generation of straight-chain alkanes and 1-olefins; Eq. (c) is the side reaction for the production of alcohols, aldehydes and other oxygenated organic compounds; Eq. (d) is the water gas shift reaction (WGS) with the Fischer-Tropsch synthesis system, it has some regulatory roles to $\mathrm{F}-\mathrm{T}$ reaction; Eq. (e) is the reaction to generate methane; and Eq. (f) is the coking reaction.

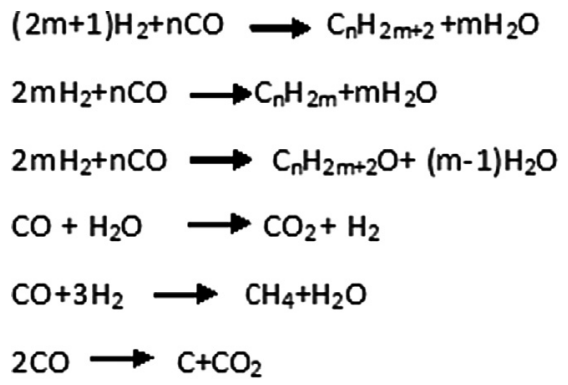

(a)

Fig. 2. Major overall reaction in the Fischer-Tropsch synthesis.

From literatures, the three major reaction mechanisms for the Fischer-Tropsch synthesis are carbide mechanism, oxygenate mechanism and CO-insertion mechanism [87-89]. None of the three mechanisms mentioned above is capable of predicting the whole product spectrum observed for the four Fischer-Tropsch metals of interest with iron, cobalt, ruthenium, and nickel. Many researchers assumed that the Fischer-Tropsch mechanism likely involves more than only one key intermediate [90-92]. From this respect, they proposed that $\mathrm{CO}$-insertion mechanism is responsible for the formation of oxygenates, while hydrocarbons are formed via the $\mathrm{O}$-free carbene mechanism. Acids are formed via the insertion of $\mathrm{CO}_{2}$. Moreover, a large variety of $\mathrm{O}-, \mathrm{H}-$, and $\mathrm{C}$-containing species are present on the catalyst surface that all may be involved in this parallel mechanism. However, this mechanism ignores the role of surface carbide growth in the carbon chain. Thus, many researchers integrated carbide condensation mechanism with oxygen intermediates and proposed a dual intermediate condensation mechanism, that the formation of methane by the carbide mechanism, while the chain growth according to intermediate condensation mechanism.

The F-T process produces a mixture of hydrocarbons $(\mathrm{HC})$ with carbon chains corresponding to gases (range from $C_{1}$ to $C_{4}$ ), liquids (from $C_{5}$ to $C_{20}$ ) and even waxes $\left(>C_{20}\right.$ ) [93]. The main products of this process were olefins, alcohols, and acids, oxygenate and paraffins of different length depending on a reactor and catalyst type. The product distribution follows the Anderson-Schulz-Flory (ASF) distribution as long as there is a constant probability of chain growth factor. The F-T approach provides a series of production of liquid fuels (including jet fuel) from various carbonaceous feedstocks, of which the most relevant are coal, natural gas, and biomass $[71,86,94]$. The first plant used coal as the starting material; this conversion is called coal-to-liquids or CTL. The current generation of plants will use natural gas as the starting material; this is called gas-to-liquids or GTL. Biomass can also be used as the starting material by going through a gasification step to produce carbon monoxide and hydrogen; this process is called biomassto-liquids or BTL.

\section{1. $C T L$}

Information from the Energy Information Administration indicates that since 2004 the use of coal as a global energy source has caught up with the use of natural gas, and would even surpass it by 2030 [95,96]. In 2006, global coal consumption rose by $4.5 \%$, which is well above the 10 -year average whereas oil consumption increased by only $0.7 \%$-the weakest growth since 2001 . Coal liquefaction could potentially be used to make jet fuel. Furthermore, the CTL has been considered as one of the more reasonable approaches for alternative liquid fuels production since 1940s. $[97,98]$. CTL provided 92\% of Germany's air fuel and over 50\% of their petroleum supply in the 1940s. Assuming near-term construction of pioneer coal-to-liquids facilities in the United States, it is estimated that approximately 75,000 barrels of jet fuel could be 
produced daily from coal within the next decade. There are some unique compositional advantages of using coal-derived liquids for making advanced jet fuels, with respect to the high-temperature thermal stability for use in future high performance aircraft [99]. Compared to conventional petroleum-derived jet fuels, the coalderived jet fuels display greater thermal stability at temperatures above $400{ }^{\circ} \mathrm{C}$ in terms of much lower degree of decomposition and significantly fewer solid deposits. This is because coal-derived jet fuels are rich in cycloalkanes and the aromatic compounds in coal-derived jet fuels can be dominated by hydroaromatic structures [100].

Current CTL capacity is limited to South Africa. Since the 1950s, South African Coal Oil and Gas Corporation (Sasol) is operating the world's two commercial CTL plants, producing about $30 \%$ $(160,000 \mathrm{bpd})$ of South Africa's automotive fuels [101]. The Chinese government intends to achieve an annual CTL production capacity of 152 million barrels in the coming 5-10 years in order to reduce oil imports by $5-10 \%$.

Coal-to-liquids (CTL) is a technology based on the liquefaction of coal using two basic approaches: direct coal liquefaction (DCL)

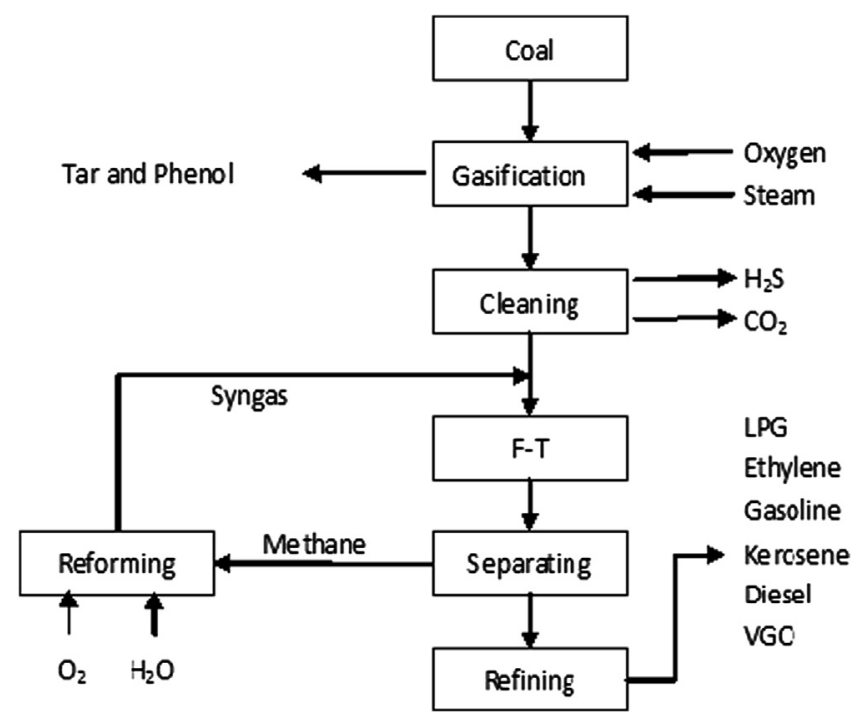

Fig. 3. Typical indirect coal liquefaction process. and indirect coal liquefaction (ICL) [102]. In indirect coal liquefaction, coal involves a complete breakdown by gasification to create a synthesis gas comprised of hydrogen and carbon monoxide. The synthetic gas is then treated to remove impurities and unwanted compounds such as mercury and sulfur capable of disturbing further reactions. With well established technology and lots of operational experience, Sasol has the only commercialscale ICL plants currently and has already produced over 1.5 billion barrels of synthetic oil. In direct coal liquefaction, coal is pulverized and mixed with oil and hydrogen in a pressurized environment. This process converts the coal into a synthetic crude oil. Even though liquid yields can be in excess of $70 \%$ of the dry weight coal, with overall thermal efficiencies of $60-70 \%$, further treatment is needed before they are usable as a transport fuel and refining stages are needed in the full process chain [103]. The direct coal liquefaction technology has been demonstrated in the United States and is now being commercially deployed in China and other countries $[104,105]$.

Coal-to-liquids (CTL) technology mainly contains three steps to get liquid products as shown in Fig. 3: gasification of coal to produce syngas ( $\mathrm{CO}$ and $\mathrm{H}_{2}$ ), followed by F-T reaction, and finally upgrade the hydrocarbons to the required products and useful chemicals. During coal gasification, the feedstock is fed into a reactor (gasifier) where the coal reacts with air or oxygen and steam. Depending on the type of gasifier, coal gasification involves pressures of 30-50 bar and temperatures in the range from $500{ }^{\circ} \mathrm{C}$ up to $1200{ }^{\circ} \mathrm{C}$. In order to obtain an optimal gas constitution for the Fischer-Tropsch synthesis, additional processes need to be carried out to raise the hydrogen content and to clean the gas from undesirable by-products, especially $\mathrm{SO}_{2}$ (sulfur dioxide) and $\mathrm{CO}_{2}$. The gas cleaning procedure is crucial as both $\mathrm{SO}_{2}$ and $\mathrm{CO}_{2}$ inhibit an optimal performance of the Fischer-Tropsch process. During this process, chemical reactions between carbon and other compounds will eventually fabricate hydrocarbon molecules of the desired length. After F-T process, the clean syngas generates a broad set of hydrocarbons, including liquids such as gasoline, diesel or jet fuel, gases such as fuel gas or liquefied petroleum gas (LPG) and waxy substances like soft or hard waxes [100]. The share of middle distillates produced via Fischer-Tropsch conversion may reach up to $75 \%$ of the obtained product mixture, including $80 \%$ diesel and $20 \%$ kerosene.

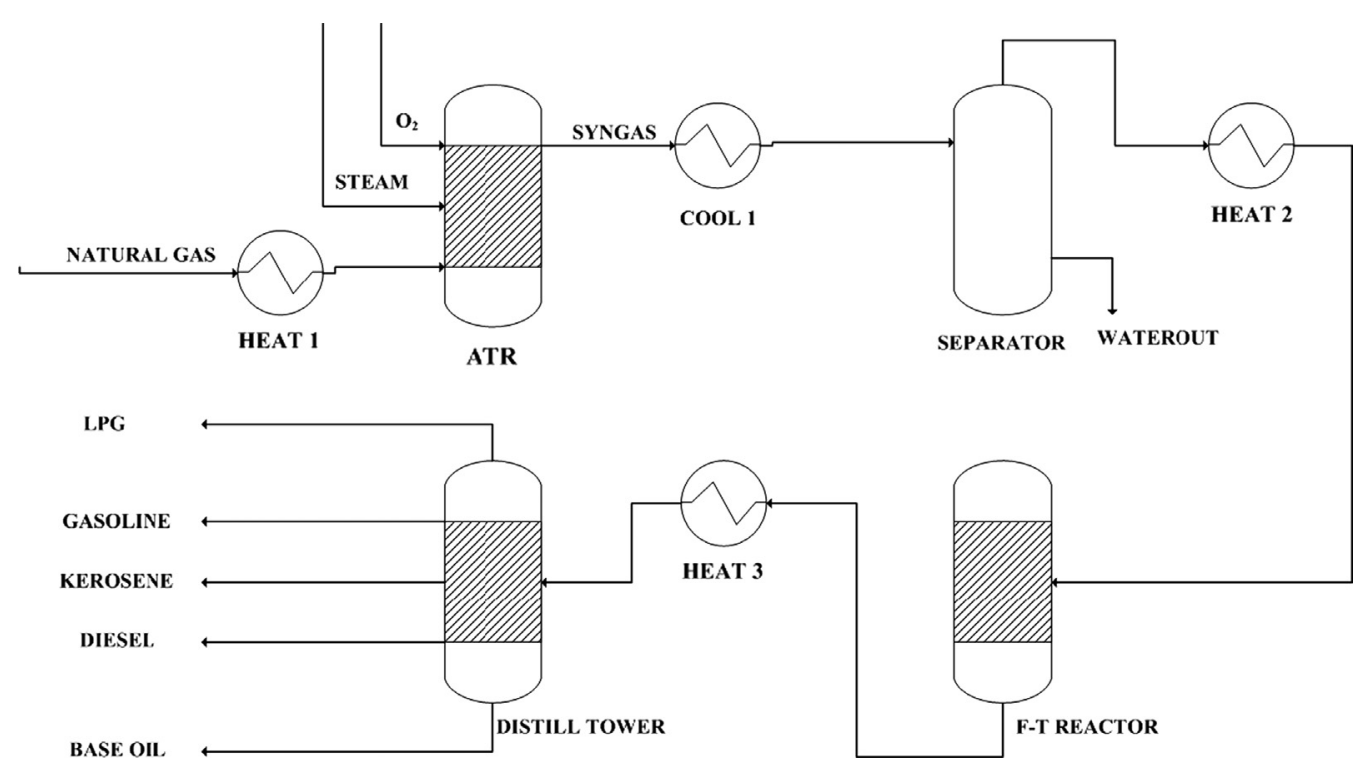

Fig. 4. The basic flow sheet of F-T based GTL technology. 
4.2. GTL

Natural gas is recognized as one of the cleanest and most abundant fossil fuels, but it is four times more expensive to transport than oil. Converting remote natural gas into a liquid before transport is more cost-effective [106]. Liquefied natural gas, which is mainly composed of methane, can serve as an alternative source [107]. Allen pointed out that the natural gas would be the dominant energy source for the next 80 years and a major question was how best to use it for aviation [108]. As the world price of oil rises early in the decade, depletion of fossil fuel and environmental pollution, considerable commercial attention was directed at the potential of GTL facilities. GTL is a well developed and proven technology and it is an important option for moving natural gas to the market place [109]. The key concept of a GTL process is to chemically convert the gas into longer-chain hydrocarbons that will typically be in the range of liquid transportation fuels and other liquid products like more valuable middle distillates and lubricants. This conversion also takes place on a surface of catalysts such as cobalt or iron via a technology known as Fischer-Tropsch (FT) synthesis. This FT-based GTL technology exhibited great environmental advantages. These include low content of $\mathrm{NO}_{X}$, aromatics and sulfur compounds that will result in measurable benefit to the environment in addition to low particulate matter generation upon combustion.

The surge in need for liquid fuels during World War II accelerated the research, development, and commercial implementation of several FT-based GTL technologies [110]. The world's first commercial-scale gas-to-liquid (GTL) plant based on integrated low-temperature F-T synthesis was built by Shell in Malaysia, began operating in 1993, and continues to produce approximately 15,000 bpd with Shell Middle Distillate Synthesis (SMDS) process. More recently Shell and Qatar Petroleum introduced the Pearl Project which uses multi-tubular fixed-bed F-T reactors to produce $140,000 \mathrm{bpd}$ capacity of liquid products primarily naphtha and transport fuel (including $12,000 \mathrm{bpd}$ of GTL kerosene) in Ras Laffan, Qatar [111]. Another large GTL project in Qatar is the Oryx GTL plant which uses technology jointly developed by Sasol and Chevron where the F-T process is based on a slurry phase distillate process (SPD) to produce $34,000 \mathrm{bpd}$. Syntroleum's GTL process has been under development since 1980s. The Sweetwater project employed the Syntroleum process to convert natural gas into ultra-clean, high performance, sulfurfree synthetic specialty products. Also in Africa, Mossgas (Pty.) Ltd produced liquid products from syngas using F-T technology licensed from Sasol and the production potential is around $22,500 \mathrm{bpd}$. Based on current planned production in Malaysia, Qatar, and South Africa, they estimated that global production of GTL in 2017 will be between 200,000 and 300,000 bpd, of which up to one-quarter, 50,000 to $75,000 \mathrm{bpd}$, could be economically dedicated to jet-fuel production. On 12 October 2009, a Qatar Airways Airbus A340-600 conducted the world's first commercial passenger flight using a mixture of kerosene and synthetic Gas-toLiquid fuel in its flight from London's Gatwick Airport to Doha.

The GTL process is mainly comprised of three steps as shown in Fig. 4: steam reforming of natural gas to produce syngas ( $\mathrm{CO}$ and $\mathrm{H}_{2}$ ), followed by $\mathrm{F}-\mathrm{T}$ reaction, and finally upgrading of the products utilizing cracking and hydro-processing units for the synthesis liquid hydrocarbons to yield higher valued chemical products that meet the market specifications. In addition, Available processes for the production of synthesis gas for GTL plants are also based on partial oxidation or combinations of partial oxidation and steam reforming $[112,113]$. Key GTL products include liquefied petroleum gas (LPG), gasoline with near zero sulfur, diesel with high cetane number, lube base-stocks and waxes, and high quality petrochemicals such as naphtha. In the syngas reforming process, the feedstock reacts with steam and oxygen to produce hydrogen, carbon monoxide and carbon dioxide. The principal technologies for producing syngas from natural gas feed were employed, such as partial oxidation (POX), catalytic steam methane reforming (SMR), two-step reforming, autothermal reforming (ATR), and heat exchange reforming [107,114,115]. Each technology has its own features. POX could use pure oxygen in the presence of a catalyst with greater selectivity and exothermicity, while SMR does not require oxygen but working in the temperature range $973-1223 \mathrm{~K}$ and under high pressure (2-4 MPa) [116]. Furthermore, the steam reforming is commercialized in large-scale application even though it is not kinetically faster than the POX but higher ratio of $\mathrm{H}_{2} / \mathrm{CO}$ is always required for further syngas conversion to produce hydrocarbons $[117,118]$. The partial oxidation could result directly in the wanted stoichiometry of the product gas and could be performed at low temperature [119]. This route provides the desired 2:1 ratio and is the preferred route in isolation of other needs [120]. There are two routes: one uses oxygen and produces a purer syngas without nitrogen; the other uses air creating a more dilute syngas [121]. However, the oxygen route requires an air separation plant that increases the cost of the investment [122]. The key influences on their competitiveness are the cost of capital, operating costs of the plant, feedstock costs, scale and ability to achieve high utilization rates in production. The ATR has the most favorable $\mathrm{H}_{2} / \mathrm{CO}$ ratio for cobalt-based catalyst and the reduction of the S/C-ratio improves the syngas composition and reduces the $\mathrm{CO}_{2}$ recycle. Heat exchange for reforming can use compact equipment and introduces flexibility to increase the overall carbon efficiency of the plant. The GTL is technically feasible to synthesize almost any hydrocarbon. And in the past five decades several processes have been developed to synthesize liquid hydrocarbons from natural gas.

\section{3. $B T L$}

Biomass can generally be defined as any hydrocarbon material which mainly consists of carbon, hydrogen, oxygen and nitrogen and less proportion of sulfur [123-125]. Biomass resources cover various forms but it has a basic structure that it is a mixture of hemicellulose, cellulose, lignin and minor amounts of other organics [126,127]. Taking into account the availability of wood chips and energy crops from forestry and agriculture, aquatic plants and algae, by-products from downstream agro- and wood based industries, as well as municipal and industrial waste streams [128-130], the theoretical worldwide potential for the production of jet fuel from currently available biomass is estimated at over 100 million barrels per day, albeit with a high degree of uncertainty [131]. According to the European Biomass Industry Association (EUBIA), the worldwide raw biomass energy potential in 2050 has been estimated to be between 150 and $450 \mathrm{EJ} / \mathrm{year}$, or $25 \times 10^{9}$ to $76 \times 10^{9}$ boe (barrels of oil energy equivalent). Europe, Africa, and Latin America could produce 8.9, 21.4 , and $19.9 \mathrm{EJ}$ of biomass per year with an energy equivalence of $1.4 \times 10^{9}, 3.5 \times 10^{9}$, and $3.2 \times 10^{9}$ boe, respectively [132].

Significant progress has been achieved on biomass production and conversion technologies over the last decade resulting in the increase of competitive, reliable and efficient technologies. Also, a variety of processes exist where biomass can be converted into biojet via biological conversion, physical conversion and thermal conversion. These processes contain the pyrolysis, gasification, anaerobic digestion, distillation, fermentation, etc [133-135]. The pyrolysis and gasification followed by the Fischer-Tropsch (F-T) synthesis process is one of the best options for the production of biojet that is currently commercially available [136]. The advantage of the BTL route to liquid transportation fuels lies in the 
ability to use almost any type of biomass, with little pre-treatment other than moisture control [137]. Besides, the required products like heavy waxy hydrocarbons with almost zero aromatics and sulfur also would be obtained depending on the operating conditions of the F-T process [138]. It is estimated that over $4 \mathrm{~m}^{3}$ of BTL-fuels can be produced per hectare of land per annum. Hence, in future if 4-6 million hectares of land were used to grow energy crops, one could replace $20-25 \%$ of the liquid transport fuel currently used.

Pyrolysis is the direct thermal decomposition of organic matrix in the absence of oxygen [139]. As input to the pyrolysis process, almost any dried and granulated feedstock is acceptable. The outputs of the pyrolysis process are volatiles (mainly contains $\mathrm{CO}_{2}, \mathrm{CO}, \mathrm{CH}_{4}, \mathrm{H}_{2}, \mathrm{C}_{2} \mathrm{H}_{6}$, and $\mathrm{C}_{2} \mathrm{H}_{4}$ ), bio-oil (modeled as $\mathrm{CH}_{1.9} \mathrm{O}$ ), char (carbon) and ash [123]. The pyrolysis process conditions that favor liquid bio-oil product (mainly is a complex mixture of water and organic chemicals) are depending on the temperature, residence time, heating rate and other reaction parameters [126, 139-141]. The most advantage of bio-oil production by pyrolysis is that it requires only a simple reactor and large percent of biomass energy can be converted into liquid products. Gasification is a thermochemical conversion process that forms synthesis gas or syngas (a mixture of $\mathrm{H}_{2}$ and $\mathrm{CO}$ ) by reacting pyrolysis products with air or steam. Gasification takes the products of pyrolysis as input and requires an oxidizing agent (typically steam). The outputs of the gasification process are hydrogen gas and carbon monoxide (that together make syngas), volatiles (represented as methane) and carbon dioxide [142]. Gasification could take place in an entrained flow reactor at high temperature [143]. Typical process conditions for gasification are temperature, $T=1200 \mathrm{~K}$ and pressure, $P=21$ bar. Once the gasification process has been completed, syngas can be further processed into hydrocarbon chains of varying length, which can be refined to isolate the desired fuel (jet fuel in this case) using techniques similar to those employed in petroleum refineries. The International Air Transport Association and McGill University investigated fundamental efficiencies of several different processes. They pointed out that the maximum energy efficiency of F-T fuel from biomass, especially hardwood, is greater than from coal or natural gas $(77 \%, 64 \%$, and $68 \%$, respectively) with the reason of that biomass is more reactive than coal and natural gas and biomass gasification can occur at lower temperature [144]. However, the biomass gasification could cause slagging and fouling problems in the conventional equipments because it contains sodium, potassium and other alkali.

The FT-based BTL technology is currently in the demonstration phase. NSE Biofuels (in partnership with Foster Wheeler and VTT) is planning to develop a commercial production plant at one of Stora Enso's mills with a project output capacity of 100,000 t/year in 2016. A German firm, CHOREN, is now constructing a small commercial BTL plant with a capacity of almost $300 \mathrm{bpd}$ of liquid product that began start-up operations in 2008. In December 2009, CEA (Atomic and Alternative Energy Commission) France announced the construction of a pilot BTL plant in Bure Saudron. The plant will use forestry and agricultural residues to produce about 23,000 /year of biofuel (diesel, kerosene and naptha). Solena Group, in partnership with Rentech, has announced plans to develop and build a BTL facility that would produce $1800 \mathrm{bpd}$ of fuel (70\% of which is JP-8 intended for the U.S. Air Force) by agricultural, forestry, and municipal waste from northern and central California; the facility is scheduled to begin construction in Gilroy, California, in 2009.

Many recent studies have investigated the potential to use a combination of coal and biomass as a feedstock for the production of coal-biomass-to-liquid (CBTL) fuels [145]. The U.S. Department of Energy's Savannah River National Laboratory has developed a new and efficient process to produce biofuels from coal and other biomass. The new single-step hydrolysis process co-converts coal and any biomass to a liquid fuel while generating a high purity carbon dioxide as a byproduct [146-148]. A coal and biomass-toliquid pilot (CBTL) project in the US state of Montana is likely to be the recipient of funding under a recent Energy and Water Appropriations bill that has released $\$ 20 \mathrm{M}$ in financing to be allocated by the Department of Energy. Montana Coal-and-Biomass-ToLiquids (CBTL) pilot project will be projected to bring hundreds of new jobs to Montana and create new markets for Montana coal and camelina. However, there is very limited information regarding the economic potential and environmental impacts of CBTL, because of no commercial-scale CBTL facility operates to date.

\section{Renewable jet fuel process}

With peak oil is approaching and environment issue continuing to gain momentum throughout the industry, everyone focused on reducing emissions, increasing efficiency and developing alternative fuels $[23,30]$. Also, the reduction of GHG emissions is a top objective in the fight against global warming. Alternative fuel is an imminent part of the aviation industry's future [15]. The aviation industry is hopeful about alternative fuels for the potential environmental benefit of reduced life cycle greenhouse gas emissions and the economic benefits associated with increased fuel availability and lower fuel costs [31]. Vegetable oils and animal fats would be hydrotreated to produce high cetane number and straight chain alkanes ranging from $C_{9}$ to $C_{18}$ that can be used in the aviation industry [149-152]. The hydrotreating process conditions are with temperature of $350-450^{\circ} \mathrm{C}$, pressure of 40 $-150 \mathrm{~atm}$, liquid hourly space velocities $0.5-5.0 \mathrm{~h}^{-1}$, and sulfided $\mathrm{NiMo} / \mathrm{Al}_{2} \mathrm{O}_{3}$ catalysts. Then the alkanes can also be isomerized using molecular sieve or zeolite catalysts [132].

Syntroleum has licensed its Bio-Synfining ${ }^{\mathrm{TM}}$ process to Dynamic fuels. Bio-Synfining TM SPK is a low capital cost process for producing high quality synthetic paraffinic kerosene (SPK) from bio-renewable feeds such as the triglycerides and/or fatty acids from animal fats, greases, vegetable and algae oils. Fig. 5 shows the basic flow sheet of Bio-Synfining ${ }^{\mathrm{TM}}$ SPK process. In BioSynfining ${ }^{\mathrm{TM}}$ SPK process, fatty acids and glycerides are converted to SPK in three steps. First, the raw feedstocks are pretreated to remove catalyst contaminants and water. $98+\%$ of the metal and phosphorus contaminants will be removed from opportunity fats and greases. In the second step, fatty acid chains are converted into n-paraffins via exothermic hydrogenation and deoxygenation reactions in a hydrotreater. In the last step of the process, the long straight-chain paraffins are hydrocracked into shorter branched paraffins. The hydrocracked products fall mainly in the kerosene and naphtha boiling range (mainly $\mathrm{C}_{15}-\mathrm{C}_{18} n$-paraffin compositions). During the first half of 2008, Syntroleum successfully produced over 600 gal of Bio-Synfining TM SPK for the U.S. Air Force. The feedstock was a blend of low quality and waste fats and greases. The 50/50 venture - known as Dynamic Fuels - was formed to construct and operate multiple renewable synthetic fuels facilities, with production on the first site beginning in 2010 .

Honeywell's UOP also has successfully commercialized the deoxygenating process to convert vegetable oils and wastes to green jet fuels by Ecofining ${ }^{\mathrm{TM}}$ SPK process. UOP has produced several thousand gallons of renewable jet fuel from a variety of feedstocks, including first generation oils such as palm and soybean oils, as well as second generation oils like camelina, jatropha and algal oils [153,154]. Working with feedstock partners Sustainable Oils, Solazyme and Cargill, Honeywell's UOP will produce up to 190,000 gallons of fuel for the Navy and 400,000 gallons for the Air Force from sustainable, non-food feedstocks including animal fats, algae and camelina. 
UOP's green jet fuel process technology (Ecofining process) consists of two main sections, deoxygenation section and isomerization/cracking (or hydrocracking) section. Both of them are based on hydroprocessing technology commonly used in today's refineries to produce transportation fuels. In the first section, hydrogen is added to remove oxygen from natural oils produced from sustainable feedstocks. The deoxygenation is highly exothermic and after this process stream enters the second section where cracking reactions occur. In the second section, the stream was selectively cracked and partially isomerized to yield a paraffinic product in the jet range. The resulting SPK can be used as a blending component with petroleum-derived JP-8 or combined with aromatics from either a renewable or petroleum source.

To meet the complete jet fuel specifications, it is necessary to have a certain percentage of aromatics in the fuel. The SPK should be blended with conventional jet fuel or with aromatics from a renewable source. In collaboration with the National Renewable Energy Laboratory and Pacific Northwest National Laboratory, UOP has obtained aromatics derived from pyrolysis oil by Rapid Thermal Processing (RTPTM process) and the resulting fuels meet the key freeze point, flash point and density specifications. The pyrolysis oil was mainly generated from two types of cellulosic biomass: corn stover and woody materials. The RTP process is a fast thermal process where biomass is rapidly heated in the absence of oxygen. The biomass is vaporized and then rapidly cooled to generate high yields of pyrolysis oil. The process utilizes a circulating transported fluidized bed reactor system similar to that used in the UOP Fluid Catalytic Cracking (FCC) technology from the petroleum industry. The process typically yields between $65 \mathrm{wt} \%$ to $75 \mathrm{wt} \%$ pyrolysis oil from dried woody biomass that can be utilized as fuel for industrial heat and electrical power

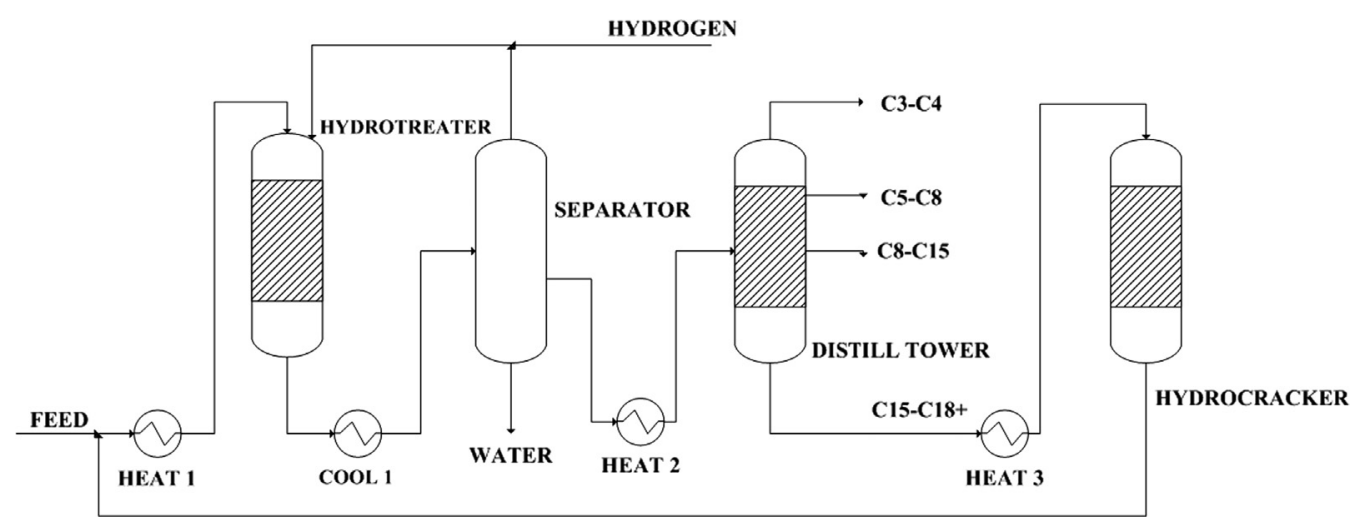

Fig. 5. The basic flow sheet of bio-synfining SPK process.

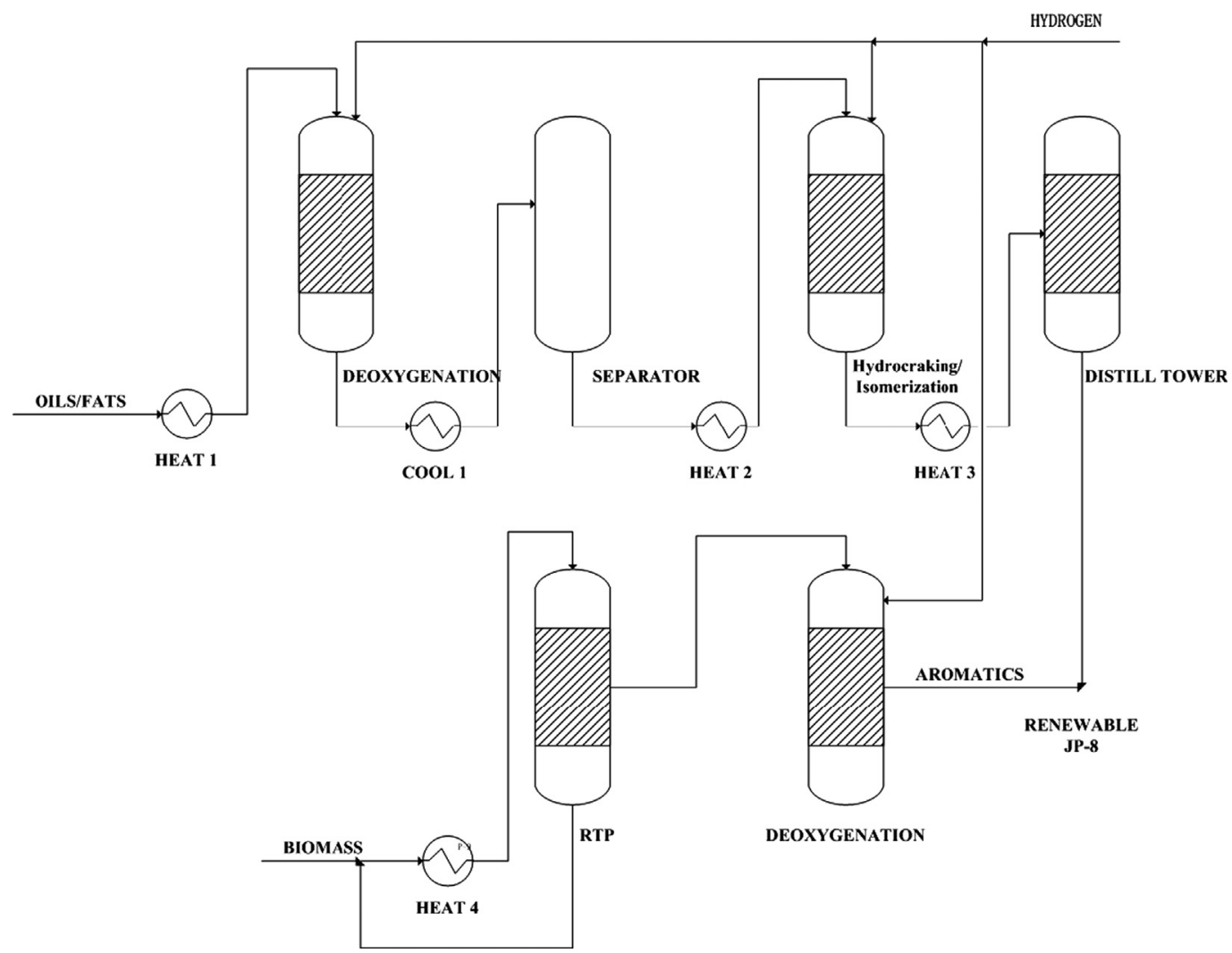

Fig. 6. The UOP renewable jet fuel process. 


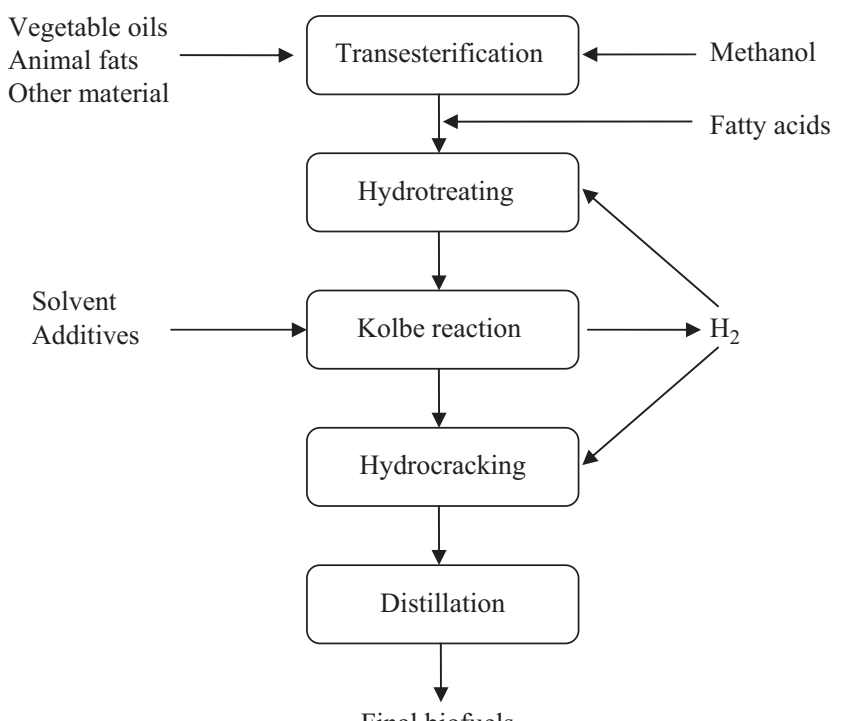

Fig. 7. The Tianjin University renewable jet fuel process.

generation. The deoxygenation involves treating pyrolysis oils at moderate temperature with high pressure $\mathrm{H}_{2}$ in the presence of heterogeneous catalysts such as sulfided CoMo and NiMo-based catalysts. During the deoxygenation, the oxygen in the pyrolysis oils reacts with $\mathrm{H}_{2}$ to form water and improves the formation of saturated $\mathrm{C}-\mathrm{C}$ bonds. The deoxygenated pyrolysis oils were then blended with UOP's renewable SPK. The basic flow sheet of UOP renewable jet fuel process as shown in Fig. 6 .

Fatty acid methyl esters (also called biodiesel) are renewable fuels manufactured by the transesterification of vegetable oils or animal fats. It was also considered as an alternative to jet fuel components with the reason that it can be used as a substitute for or as an additive to mineral diesel. However, its poor lowtemperature properties and high oxygen content limit its wide commercial application as jet fuel component. Tianjin University developed a new method ( $\mathrm{C}-\mathrm{L}^{\mathrm{TM}}$ process) to produce wide-cut aviation biofuel (carbon number ranged from 5 to 15) from fatty acid methyl esters (as shown in Fig. 7). There are three main steps in this technology. First, the feedstock fatty acids or fatty acid methyl esters were hydrotreated to eliminate the side effect of double bonds. The products from the hydrotreating process undergo the Kolbe reactions to convert into long chain hydrocarbons. The optimum conditions for Kolbe reaction were that the potential was higher than $7.5 \mathrm{~V}$ and $20 \mathrm{wt} \%$ of $\mathrm{KOH}$ was used as the support electrolyte with temperature of $45 \pm 5{ }^{\circ} \mathrm{C}$, while the methanol as solvent. At last, the hydrocracking process was used to change long chain hydrocarbons into desired jet fuels, which have similar properties with bio-SPK obtained from UOP's Ecofining ${ }^{\text {TM }}$ SPK process. However, this process could undergo effectively at lower hydrogen pressure and the hydrogen consumed during the whole process would be supplied by this closed system itself (hydrogen was byproduct during Kolbe electrosynthesis).

\section{Concluding remarks}

Recently, aviation industries are looking for new methods and technologies to address the growing pressures on the environmental and economical aspects. Although pollutant emissions from aircrafts and high operating costs are mainly determined by the company managements and technology of the engines, aviation fuel composition also plays a significant role. The development of sustainable alternative aviation jet fuel would be an imminent part of the aviation industry's future. In this paper, four types of jet fuel production technologies, including the crude oilbased conventional process, unconventional oil sources-based process, the Fischer-Tropsch synthesis (F-T) process and the renewable jet fuel process, were performed.

The crude oil-based conventional process is still the dominant technology for the production of aviation jet fuels all over the world. However, the large fluctuations in the cost of fuel and great concerns on emission as well as reduction of crude oil production have provided a strong incentive for airlines to consider alternative sources of fuel. Even though the Jet fuels produced from unconventional resources (oil sands, VHOs, and oil shale) currently have certain potential supplement and could meet all specifications for Jet $\mathrm{A}$, high investment and $\mathrm{CO}_{2}$ collection (or storage) would be the biggest obstacle for the wide application of this technology. Among these jet fuel technologies, the F-T synthesis process and the renewable jet fuel process will supply alternative fuels for the potential environmental benefit of reduced life cycle greenhouse gas (GHG) emissions and the economic benefits associated with increased fuel availability and lower fuel costs.

The F-T approach provides a method of producing liquid fuels (including jet fuel) with similar characteristics from various carbonaceous feedstocks, of which the most relevant are natural gas, coal, and biomass. It is often regarded as the key technological component for converting synthesis gas to transportation fuels and other liquid products. However, syngas production itself accounts for more than half the capital investment. The availability of F-T jet fuels within the next decade depends on feedstock, the world price of oil, resolving uncertainties in production costs, and regulatory and technical issues associated with capturing and sequestering large quantities of $\mathrm{CO}_{2}$.

All renewable jet fuel processes such as Bio-Synfining ${ }^{\mathrm{TM}}$ (Syntroleum) and Ecofining ${ }^{\mathrm{TM}}$ (UOP) as well as $\mathrm{C}^{-\mathrm{L}^{\mathrm{TM}}}$ process (Tianjin University) are low capital cost processes for producing high quality synthetic paraffinic kerosene (SPK) from bio-renewable feedstocks like vegetable oils, animal fats, greases, jatropha, algal and wastes. The SPK has superior product properties to other options available today, with higher cetane number, lower cloud point and lower emissions. The renewable jet fuel SPK can be used in today's tanks, pipelines, pumps and automobiles without any changes that it will safe significant expense as demand for renewable grows.

\section{References}

[1] Hihara K. Analysis on bargaining about global climate change mitigation in international aviation sector. Transportation Research Part E-Logistics and Transportation Review 2011;47(3):342-58.

[2] Lee DS, Fahey DW, Forster PM, Newton PJ, Wit RCN, Lim LL et al. Aviation and global climate change in the 21st century. Atmospheric Environment 2009;43(22-23):3520-37.

[3] Grabar VA, Gitarskii ML, Dmitrieva TM, Glukhovskaya EP, Khor'kova NI, Kirichkov SV. Assessment of greenhouse gases emission from civil aviation in Russia. Russian Meteorology and Hydrology 2011;36(1):18-24.

[4] Lee DS, Pitari G, Grewe V, Gierens K, Penner JE, Petzold A, et al. Transport impacts on atmosphere and climate: aviation. Atmospheric Environment 2010;44(37):4678-734.

[5] Mayor K. Tol RSJ. The impact of European climate change regulations on international tourist markets. Transportation Research Part D-Transport and Environment 2010;15(1):26-36.

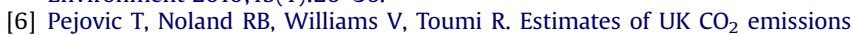
from aviation using air traffic data. Climatic Change 2008;88(3-4):367-84.

[7] Saidur R, Rahim NA, Masjuki HH, Mekhilef S, Ping HW, Jamaluddin MF. Enduse energy analysis in the Malaysian industrial sector. Energy 2009;34 (2):153-8.

[8] Commodo M, Wong O, Fabris I, Groth CPT, Gulder OL. Spectroscopic study of aviation jet fuel thermal oxidative stability. Energy and Fuels 2010;24: 6437-41.

[9] Dunn PF, Thomas FO, Davis MP, Dorofeeva IE. Experimental characterization of aviation-fuel cavitation. Physics of Fluids 2010;22(11). http://dx.doi.org/ $10.1063 / 1.3490051$. 
[10] Dunn PF, Thomas FO, Leighton JB, Lv D. Determination of Henry's law constant and the diffusion and polytropic coefficients of air in aviation fuel. Fuel 2011;90(3):1257-63.

[11] Maurice LQ Lander H, Edwards T, Harrison WE. Advanced aviation fuels: a look ahead via a historical perspective. Fuel 2001;80(5):747-56.

[12] Gupta KK, Rehman A, Sarviya RM. Bio-fuels for the gas turbine: a review. Renewable and Sustainable Energy Reviews 2010;14:2946-55.

[13] Waynick JA. The development and use of metal deactivators in the petroleum industry: a review. Energy and Fuels 2001;15(6):1325-40.

[14] Chavez-Rodriguez MF, Nebra SA. Assessing GHG emissions, ecological footprint, and water linkage for different fuels. Environmental Science and Technology 2010;44(24):9252-7.

[15] Blakey S, Rye L, Wilson CW. Aviation gas turbine alternative fuels: a review. Proceedings of the Combustion Institute 2011;33:2863-85.

[16] Macintosh A, Wallace L. International aviation emissions to 2025: can emissions be stabilised without restricting demand? Energy Policy 2009;37 (1):264-73.

[17] Stratton RW, Wolfe PJ, Hileman JI. Impact of aviation Non- $\mathrm{CO}(2)$ combustion effects on the envinmental feasibility of alternative jet fuels. Environmental Science and Technology 2011;45(24):10736-43.

[18] Morrell P. An evaluation of possible EU air transport emissions trading scheme allocation methods. Energy Policy 2007;35(11):5562-70.

[19] Scheelhaase J, Grimme W, Schaefer M. The inclusion of aviation into the EU emission trading scheme-impacts on competition between European and non-European network airlines. Transportation Research Part D-Transport and Environment 2010;15(1):14-25.

[20] Arto I, Gallastegui C, Ansuategi A. Accounting for early action in the European Union Emission Trading Scheme. Energy Policy 2009;37 (10):3914-24.

[21] Jaehn F, Letmathe P. The emissions trading paradox. European Journal of Operational Research 2010;202(1):248-54.

[22] Kockar I, Conejo AJ, McDonald JR. Influence of the Emissions Trading Scheme on generation scheduling. International Journal of Electrical Power and Energy Systems 2009;31(9):465-73.

[23] Perch-Nielsen S, Sesartic A, Stucki M. The greenhouse gas intensity of the tourism sector: the case of Switzerland. Environmental Science and Policy 2010;13(2):131-40.

[24] Pope J, Owen AD. Emission trading schemes: potential revenue effects, compliance costs and overall tax policy issues. Energy Policy 2009;37 (11):4595-603.

[25] Aravossis K, Garoufi G. The impact of the emission trading system on companies' profitability: the case of Greece. Environmental Economics and Investment Assessment III 2010;131:3-15

[26] Persson TA. Linking the Northeast states of the US mitigation program to the EU Emission Trading Scheme-implications and costs. Mitigation and Adaptation Strategies for Global Change 2009;14(5):399-408.

[27] Tomas RAF, Ribeiro FR, Santos VMS, Gomes JFP, Bordado JCM. Assessment of the impact of the European $\mathrm{CO}_{2}$ emissions trading scheme on the Portuguese chemical industry. Energy Policy 2010;38(1):626-32.

[28] Sehra AK, Whitlow W. Propulsion and power for 21st century aviation. Progress in Aerospace Sciences 2004:40:199-235.

[29] Gokalp I, Lebas E. Alternative fuels for industrial gas turbines (AFTUR). Applied Thermal Engineering 2004;24(11-12):1655-63.

[30] McCollum D, Yang C. Achieving deep reductions in US transport greenhouse gas emissions: scenario analysis and policy implications. Energy Policy 2009;37(12):5580-96

[31] Michaelis L. Transport sector-strategies markets, technology and innovation. Energy Policy 1997;25(14-15):1163-71.

[32] Bailis RE, Bake JE. Greenhouse gas emissions and land use change from jatropha curcas-based jet fuel in Brazil. Environmental Science and Technology 2010;44(22):8684-91.

[33] Corporan E, Edwards T, Shafer L, DeWitt MJ, Klingshirn C, Zabarnick S, et al. Chemical, thermal stability, seal swell, and emissions studies of alternative jet fuels. Energy and Fuels 2011;25(3):955-66.

[34] Hileman JI, Stratton RW, Donohoo PE. Content and alternative jet fuel viability. Journal of Propulsion and Power 2010;26(6):1184-95.

[35] Moses CA, Roets PNJ. Properties, characteristics, and combustion performance of Sasol fully synthetic jet fuel. Berlin, Germany: 53rd ASME Turbo Expo 2008; 2008.

[36] Edwards T. Liquid fuels and propellants for aerospace propulsion: 19032003. Journal of propulsion and power 2003;19(6):1089-107.

[37] BP. BP statistical review of world energy; 2008.

[38] Dagaut P, Cathonnet M. The ignition, oxidation, and combustion of kerosene: a review of experimental and kinetic modeling. Progress in Energy and Combustion Science 2006;32(1):48-92.

[39] White RD. Refining and blending of aviation turbine fuels. Tri-Service/EPA ATSDR Toxicology conference on issues and applications in toxicology and risk assessment. Wright Patterson Afb: Ohio; 1998.

[40] Gomez-Carracedo MP, Andrade JM, Calvino MA, Prada D, Fernandez E, Muniategui S. Generation and mid-IR measurement of a gas-phase to predict security parameters of aviation jet fuel. Talanta 2003;60(5):1051-62.

[41] Koroneos C, Dompros A, Roumbas G, Moussiopoulos N. Life cycle assessment of kerosene used in aviation. International Journal of Life Cycle Assessment 2005;10(6):417-24.

[42] Bernabei M, Reda R, Galiero R, Bocchinfuso G Determination of total and polycyclic aromatic hydrocarbons in aviation jet fuel. In: Proceedings of the 25th international symposium on capillary chromatography Riva Del Garda, Italy; 2002.

[43] Gokulakrishnan P, Gaines G, Currano J, Klassen MS, Roby RJ. Experimental and kinetic modeling of kerosene-type fuels at gas turbine operating conditions. Reno, NV: 50th ASME Turbo-Expo 2005; 2005.

[44] Long J, Drelich J, Xu ZH, Masliyah JH. Effect of operating temperature on water-based oil sands processing. Canadian Journal of Chemical Engineering 2007;85(5):726-38.

[45] Jiang CQ, Larter SR, Noke KJ, Snowdon LR. TLC-FID (Iatroscan) analysis of heavy oil and tar sand samples. Organic Geochemistry 2008;39(8):1210-4.

[46] Al-Otoom A, Allawzi M, Al-Harahsheh AM, Al-Harahsheh M, Al-Ghbari R, Al-Ghazo R, et al. A parametric study on the factors affecting the froth floatation of Jordanian tar sand utilizing a fluidized bed floatator. Energy 2009;34(9):1310-4.

[47] Kok MV, Pamir MR. Comparative pyrolysis and combustion kinetics of oil shales. Journal of Analytical and Applied Pyrolysis 2000;55(2):185-94.

[48] Lo CC, Brownlee BG, Bunce NJ. Mass spectrometric and toxicological assays of Athabasca oil sands naphthenic acids. Water Research 2006;40(4):655-64.

[49] Adams J, Riediger C, Fowler M, Larter S. Thermal controls on biodegradation around the Peace River tar sands: paleo-pasteurization to the west. Journal of Geochemical Exploration 2006;89(1-3):1-4.

[50] Masliyah J, Zhou ZJ, Xu ZH, Czarnecki J, Hamza H. Understanding waterbased bitumen extraction from athabasca oil sands. Canadian Journal of Chemical Engineering 2004;82(4):628-54.

[51] Hupka J, Miller JD, Drelich J. Water-based bitumen recovery from diluentconditioned oil sands. Canadian Journal of Chemical Engineering 2004;82 (5):978-85.

[52] Al-Otoom A, Allawzi M, Al-Omari N, Al-Hsienat E. Bitumen recovery from Jordanian oil sand by froth flotation using petroleum cycles oil cuts. Energy 2010;35(10):4217-25.

[53] Painter P, Williams P, Lupinsky A. Recovery of bitumen from Utah tar sands using ionic liquids. Energy and Fuels 2010;24:5081-8.

[54] Painter P, Williams P, Mannebach E. Recovery of bitumen from oil or tar sands using ionic liquids. Energy and Fuels 2010;24:1094-8.

[55] Pakdel H, Roy C. Recovery of bitumen by vacuum pyrolysis of Alberta tar sands. Energy and Fuels 2003;17(5):1145-52.

[56] Torrente MC, Galan MA. Kinetics of the thermal decomposition of oil shale from Puertollano (Spain). Fuel 2001;80(3):327-34.

[57] Gersten J, Fainberg V, Hetsroni G, Shindler Y. Kinetic study of the thermal decomposition of polypropylene, oil shale, and their mixture. Fuel 2000;79 (13):1679-86.

[58] Williams PT, Ahmad N. Influence of process conditions on the pyrolysis of Pakistani oil shales. Fuel 1999;78(6):653-62.

[59] Wang Q, Zhao WZ, Liu HP, Jia CX, Li SH. Interactions and kinetic analysis of oil shale semi-coke with cornstalk during co-combustion. Applied Energy 2011;88(6):2080-7.

[60] Jaber JO, Probert SD. Non-isothermal thermogravimetry and decomposition kinetics of two Jordanian oil shales under different processing conditions. Fuel Processing Technology 2000;63(1):57-70.

[61] Olukcu N, Yanik J, Saglam M, Yuksel M, Karaduman M. Solvent effect on the extraction of Beypazari oil shale. Energy and Fuels 1999;13(4):895-902.

[62] Torrente MC, Galan MA. Extraction of kerogen from oil shale (Puertollano, Spain) with supercritical toluene and methanol mixtures. Industrial and Engineering Chemistry Research 2011;50(3):1730-8.

[63] Abourriche A, Adil A, Oumam M, Hannache H, Pailler R, Naslain R, et al. New pitches with very significant maturation degree obtained by supercritical extraction of Moroccan oil shales. Journal of Supercritical Fluids 2008;47 (2):195-9.

[64] Sinag A, Canel M. Comparison of retorting and supercritical extraction techniques on gaining liquid products from Goynuk oil shale (Turkey). Energy Sources 2004;26(8):739-49.

[65] Koel M, Ljovin S, Bondar Y. Supercritical carbon dioxide extraction of Estonian oil shale. Oil Shale 2000;17(3):225-32.

[66] Luik H, Blyakhina I, Luik L. Liquefaction of Estonian oil shale kerogen in suband supercritical ether medium-2. Composition of liquid products. Oil Shale 2002;19(4):355-72.

[67] Koel M. Use of ionic liquids in oil shale processing. Ionic Liquids IIIB: Fundamentals, Progress, Challenges and Opportunities: Transformations and Processes 2005;902:72-82.

[68] Furimsky E. Emissions of carbon dioxide from tar sands plants in Canada. Energy and Fuels 2003;17(6):1541-8.

[69] Jalama K, Coville NJ, Xiong HF, Hildebrandt D, Glasser D, Taylor S, et al. A comparison of $\mathrm{Au} / \mathrm{Co} / \mathrm{Al}_{2} \mathrm{O}_{3}$ and $\mathrm{Au} / \mathrm{Co} / \mathrm{SiO}_{2}$ catalysts in the Fischer-Tropsch reaction. Applied Catalysis A-General 2011;395(1-2):1-9.

[70] Khodakov AY, Chu W, Fongarland P. Advances in the development of novel cobalt Fischer-Tropsch catalysts for synthesis of long-chain hydrocarbons and clean fuels. Chemical Reviews 2007;107(5):1692-744.

[71] Demirbas A. Biofuels sources, biofuel policy, biofuel economy and global biofue projections. Energy Conversion and Management 2008;49(8):2106-16.

[72] Lobo P, Hagen DE, Whitefield PD. Comparison of PM emissions from a commercial jet engine burning conventional, biomass, and Fischer-Tropsch fuels. Environmental Science and Technology 2011;45(24):10744-9.

[73] Martinez A, Lopez C, Marquez F, Diaz I. Fischer-Tropsch synthesis of hydrocarbons over mesoporous Co/SBA-15 catalysts: the influence of metal loading, cobalt precursor, and promoters. Journal of Catalysis 2003;220 (2):486-99. 
[74] Yang JH, Kim H-J, Chun DH, Lee H-T, Hong J-C, Jung H, et al. Mass transfer limitations on fixed-bed reactor for Fischer-Tropsch synthesis. Fuel Processing Technology 2010;91(3):285-9.

[75] Bermudez V, Lujan JM, Pla B, Linares WG. Comparative study of regulated and unregulated gaseous emissions during NEDC in a light-duty diese engine fuelled with Fischer Tropsch and biodiesel fuels. Biomass and Bioenergy 2011;35(2):789-98

[76] Kang SH, Bae JW, Cheon JY, Lee YJ, Ha KS, Jun KW, et al. Catalytic performance on iron-based Fischer-Tropsch catalyst in fixed-bed and bubbling fluidized-bed reactor. Applied Catalysis B-Environmental 2011;103(1-2):169-80.

[77] Jia LH, Jia LT, Li DB, Hou B, Wang JG, Sun YH. Silylated Co/SBA-15 catalysts for Fischer-Tropsch synthesis. Journal of Solid State Chemistry 2011;184 (3):488-93.

[78] Cano LA, Cagnoli MV, Bengoa JF, Alvarez AM, Marchetti SG. Effect of the activation atmosphere on the activity of Fe catalysts supported on SBA-15 in the Fischer-Tropsch synthesis. Journal of Catalysis 2011;278(2):310-20.

[79] Bezemer GL, Bitter JH, Kuipers H, Oosterbeek H, Holewijn JE, Xu XD, et al Cobalt particle size effects in the Fischer-Tropsch reaction studied with carbon nanofiber supported catalysts. Journal of the American Chemica Society 2006;128(12):3956-64.

[80] Hilmen AM, Schanke D, Hanssen KF, Holmen A. Study of the effect of water on alumina supported cobalt Fischer-Tropsch catalysts. Applied Catalysis AGeneral 1999;186(1-2):169-88.

[81] Leckel D. Diesel production in coal-based high-temperature Fischer-Tropsch plants using fixed bed dry bottom gasification technology. Fuel Processing Technology 2011;92(5):959-69.

[82] de la Osa AR, De Lucas A, Romero A, Valverde JL, Sanchez P. Fischer-Tropsch diesel production over calcium-promoted Co/alumina catalyst: effect of reaction conditions. Fuel 2011;90(5):1935-45.

[83] Jacobs G, Das TK, Zhang YQ Li JL, Racoillet G, Davis BH. Fischer-Tropsch synthesis: support, loading, and promoter effects on the reducibility of cobalt catalysts. Applied Catalysis A-General 2002;233(1-2):263-81.

[84] Feyzi M, Irandoust M, Mirzaei AA. Effects of promoters and calcination conditions on the catalytic performance of iron-manganese catalysts for Fischer-Tropsch synthesis. Fuel Processing Technology 2011;92(5):1136-43.

[85] Rafiq MH, Jakobsen HA, Schmid R, Hustad JE. Experimental studies and modeling of a fixed bed reactor for Fischer-Tropsch synthesis using biosyngas. Fuel Processing Technology 2011;92(5):893-907.

[86] Atashi H, Siami F, Mirzaei AA, Sarkari M. Kinetic study of Fischer-Tropsch process on titania-supported cobalt-manganese catalyst. Journal of Industrial and Engineering Chemistry 2010;16(6):952-61.

[87] Van der Laan GP, Beenackers A. Kinetics and selectivity of the FischerTropsch synthesis: a literature review. Catalysis Reviews-Science and Engineering 1999;41(3-4):255-318.

[88] van Berge PJ, van de Loosdrecht J, Barradas S, van der Kraan AM. Oxidation of cobalt based Fischer-Tropsch catalysts as a deactivation mechanism. Catalysis Today 2000;58(4):321-34.

[89] Schulz H. Short history and present trends of Fischer-Tropsch synthesis. Applied Catalysis A-General 1999;186(1-2):3-12.

[90] Dry ME. Practical and theoretical aspects of the catalytic Fischer-Tropsch process. Applied Catalysis A: General 1996;138(2):319-44

[91] Dry ME. The Fischer-Tropsch process: 1950-2000. Catalysis Today 2002;71 (3-4):227-41.

[92] Adesina AA. Hydrocarbon synthesis via Fischer-Tropsch reaction: travails and triumphs. Applied Catalysis A: General 1996:138(2):345-67.

[93] Blanco AAG, Amaya MG, Jalil MER, Nazzarro M, Oliva MI, Sapag K. Effect of the synthesis method on Co-catalysts based on MCM-41 for the FischerTropsch reaction. Topics in Catalysis 2011;54(1-4):190-200.

[94] Chum HL, Overend RP. Biomass and renewable fuels. Fuel Processing Technology 2001;71(1-3):187-95.

[95] Yu GW, Xu YY, Hao X, Li YW, Liu GQ. Process analysis for polygeneration of Fischer-Tropsch liquids and power with $\mathrm{CO}_{2}$ capture based on coal gasification. Fuel 2010;89(5):1070-6.

[96] Sudiro M, Bertucco A, Ruggeri F, Fontana A. Improving process performances in coal gasification for power and synfuel production. Energy and Fuels 2008;22(6):3894-901.

[97] Ou XM, Yan XY, Zhang XL. Using coal for transportation in China: life cycle GHG of coal-based fuel and electric vehicle, and policy implications. International Journal of Greenhouse Gas Control 2010;4(5):878-87.

[98] Sudiro M, Bertucco A. Production of synthetic gasoline and diesel fuel by alternative processes using natural gas and coal: process simulation and optimization. Energy 2009;34(12):2206-14.

[99] Lamprecht D. Fischer-Tropsch fuel for use by the US Military as battlefielduse fuel of the future. Energy and Fuels 2007;21(3):1448-53.

[100] Leckel D. Low-pressure hydrocracking of coal-derived Fischer-Tropsch waxes to diesel. Energy and Fuels 2007;21(3):1425-31.

[101] Vallentin D. Policy drivers and barriers for coal-to-liquids (CtL) technologies in the United States. Energy Policy 2008;36(8):3198-211.

[102] Hook M, Aleklett K. A review on coal-to-liquid fuels and its coal consumption. International Journal of Energy Research 2010;34(10):848-64.

[103] Lamprecht D, Nel R, Leckel D. Production of on-specification fuels in coal-toliquid (CTL) Fischer-Tropsch plants based on fixed-bed dry bottom coal gasification. Energy and Fuels 2010;24:1479-86.

[104] Jaramillo P, Griffin WM, Matthews HS. Comparative analysis of the production costs and life-cycle GHG emissions of FT liquid fuels from coal and natural gas. Environmental Science and Technology 2008;42(20):7559-65.
[105] Hao X, Dong GQ Yang Y, Xu YY, Li YW. Coal to liquid (CTL): Commercialization prospects in china. Chemical Engineering and Technology 2007;30(9):1157-65.

[106] Wang HH, Feldhoff A, Caro J, Schiestel T, Werth S. Oxygen selective ceramic hollow fiber membranes for partial oxidation of methane. AICHE Journal 2009;55(10):2657-64.

[107] Seo JG, Youn MH, Cho KM, Park S, Song IK. Hydrogen production by steam reforming of liquefied natural gas over a nickel catalyst supported on mesoporous alumina xerogel. Journal of Power Sources 2007;173(2):943-9.

[108] Allen JE. Global energy issues affecting aeronautics: a reasoned conjecture. Progress in Aerospace Sciences 1999;35:413-53.

[109] Rahimpour MR, Mirvakili A, Paymooni K. Simultaneous hydrogen production and utilization via coupling of Fischer-Tropsch synthesis and decalin dehydrogenation reactions in GTL technology. International Journal of Hydrogen Energy 2011;36(4):2992-3006.

[110] Keshav TR, Basu S. Gas-to-liquid technologies: India's perspective. Fuel Processing Technology 2007;88(5):493-500.

[111] Wilhelm DJ, Simbeck DR, Karp AD, Dickenson RL. Syngas production for gasto-liquids applications: technologies, issues and outlook. Fuel Processing Technology 2001;71(1-3):139-48.

[112] Wang YQ Wang WJ, Hong XB, Li BB. Zirconia promoted metallic nickel catalysts for the partial oxidation of methane to synthesis gas. Catalysis Communications 2009;10(6):940-4.

[113] Tan XY, Thursfield A, Metcalfe IS, Li K. Analysis of a perovskite ceramic hollow fibre membrane reactor for the partial oxidation of methane to syngas. AsiaPacific Journal of Chemical Engineering 2009;4(3):251-8

[114] Bakkerud PK. Update on synthesis gas production for GTL. Catalysis Today 2005;106(1-4):30-3.

[115] Faraji S, Nordheden KJ, Stagg-Williams SM. The interaction between SrFe$\mathrm{Co}_{0.5} \mathrm{O}_{(\mathrm{x})}$ ceramic membranes and $\mathrm{Pt} / \mathrm{CeZrO}_{2}$ during syngas production from methane. Catalysis Letters 2009;131(1-2):114-21.

[116] Lu H, Tong JH, Cong Y, Yang WS. Partial oxidation of methane in $\mathrm{Ba}_{0.5} \mathrm{Sr}_{0.5^{-}}$ $\mathrm{Co}_{0.8} \mathrm{Fe}_{0.2} \mathrm{O}_{3}$-delta membrane reactor at high pressures. Catalysis Today 2005;104(2-4):154-9.

[117] Delbos C, Lebain G, Richet N, Bertail C. Performances of tubular $\mathrm{La}_{0.8} \mathrm{Sr}_{0.2}$ $\mathrm{Fe}_{0.7} \mathrm{Ga}_{0.3} \mathrm{O}_{3}$-delta mixed conducting membrane reactor for under pressure methane conversion to syngas. Catalysis Today 2010;156(3-4):146-52.

[118] Hong XB, Wang YQ. Partial oxidation of methane to syngas catalyzed by a nickel nanowire catalyst. Journal of Natural Gas Chemistry 2009;18(1):98-103.

[119] Zhu XF, Li QM, He YF, Cong Y, Yang WS. Oxygen permeation and partial oxidation of methane in dual-phase membrane reactors. Journal of Membrane Science 2010;360(1-2):454-60.

[120] Tan XY, Li K. Design of mixed conducting ceramic membranes/reactors for the partial oxidation of methane to syngas. AICHE Journal 2009;55(10):2675-85.

[121] Yin X, Hong L. Partial oxidation of methane to syngas over the catalyst derived from double perovskite $\left(\mathrm{La}_{0.5} \mathrm{Sr}_{0.5}\right)(2) \mathrm{FeNiO}_{6}$-delta. Applied Catalysis A-General 2009;371(1-2):153-60.

[122] Li QM, Zhu XF, He YF, Yang WS. Partial oxidation of methane in $\mathrm{BaCe}_{0.1-}$ $\mathrm{Co}_{0.4} \mathrm{Fe}_{0.5} \mathrm{O}_{3}$-delta membrane reactor. Catalysis Today 2010;149(1-2):185-90.

[123] Yaman S. Pyrolysis of biomass to produce fuels and chemical feedstocks. Energy Conversion and Management 2004;45(5):651-71.

[124] Valdez-Vazquez I, Acevedo-Benitez JA, Hernandez-Santiago C. Distribution and potential of bioenergy resources from agricultural activities in Mexico. Renewable and Sustainable Energy Reviews 2010;14(7):2147-53.

[125] Mohamed AR, Mohammadi M, Darzi GN. Preparation of carbon molecular sieve from lignocellulosic biomass: a review. Renewable and Sustainable Energy Reviews 2010;14(6):1591-9.

[126] Bridgwater AV. Principles and practice of biomass fast pyrolysis processes for liquids. Journal of Analytical and Applied Pyrolysis 1999;51(1-2):3-22.

[127] Sims REH, Mabee W, Saddler JN, Taylor M. An overview of second generation biofuel technologies. Bioresource Technology 2010;101:1570-80.

[128] Dupont C, Rouge S, Berthelot A, Perez DS, Graffin A, Labalette F, et al. Bioenergy II: suitability of wood chips and various biomass types for use in plant of BtL production by gasification. International Journal of Chemical Reactor Engineering 2010:8.

[129] Henrich E, Dahmen N, Dinjus E. Cost estimate for biosynfuel production via biosyncrude gasification. Biofuels Bioproducts and Biorefining-Biofpr 2009;3 (1):28-41.

[130] Higo M, Dowaki KA. Life cycle analysis on a Bio-DME production system considering the species of biomass feedstock in Japan and Papua New Guinea. Applied Energy 2010;87(1):58-67.

[131] IATA. Report on alternative fuels; 2008.

[132] Huber GW, Iborra S, Corma A. Synthesis of transportation fuels from biomass: chemistry, catalysts, and engineering. Chemical Reviews 2006;106 (9):4044-98.

[133] Corma A, Iborra S, Velty A. Chemical routes for the transformation of biomass into chemicals. Chemical Reviews 2007;107(6):2411-502.

[134] Bridgwater AV. Renewable fuels and chemicals by thermal processing of biomass. Chemical Engineering Journal 2003;91(2-3):87-102.

[135] Lin Y, Tanaka S. Ethanol fermentation from biomass resources: current state and prospects. Applied Microbiology and Biotechnology 2006;69(6):627-42.

[136] Hanaoka T, Liu YY, Matsunaga K, Miyazawa T, Hirata S, Sakanishi K. Benchscale production of liquid fuel from woody biomass via gasification. Fuel Processing Technology 2010;91(8):859-65.

[137] Tijmensen MJA, Faaij APC, Hamelinck CN, van Hardeveld MRM. Exploration of the possibilities for production of Fischer Tropsch liquids and power via biomass gasification. Biomass and Bioenergy 2002;23(2):129-52. 
[138] Lappas AA, Iatridis DK, Vasalos IA. Production of liquid biofuels in a fluid catalytic cracking pilot-plant unit using waxes produced from a biomass-toliquid (BTL) process. Industrial and Engineering Chemistry Research 2011;50 (2):531-8.

[139] Mohan D, Pittman CU, Steele PH. Pyrolysis of wood/biomass for bio-oil: a critical review. Energy and Fuels 2006;20(3):848-89.

[140] Bridgwater AV, Peacocke GVC. Fast pyrolysis processes for biomass. Renewable and Sustainable Energy Reviews 2000;4(1):1-73.

[141] Czernik S, Bridgwater AV. Overview of applications of biomass fast pyrolysis oil. Energy and Fuels 2004;18(2):590-8.

[142] van Steen E, Claeys M. Fischer-Tropsch catalysts for the Biomass-to Liquid process. Chemical Engineering and Technology 2008;31(5):655-66.

[143] Seiler JM, Hohwiller C, Imbach J, Luciani JF. Technical and economical evaluation of enhanced biomass to liquid fuel processes. Energy 2010;35 (9):3587-92.

[144] IATA. Report on alternative fuels; 2009.

[145] Fermoso J, Arias B, Gil MV, Plaza MG, Pevida C, Pis JJ, et al. Co-gasification of different rank coals with biomass and petroleum coke in a high-pressure reactor for $\mathrm{H}_{2}$-rich gas production. Bioresource Technology 2010;101(9):3230-5.

[146] Demirbas A. Combustion characteristics of different biomass fuels. Progress in Energy and Combustion Science 2004;30(2):219-30.

[147] Sami M, Annamalai K, Wooldridge M. Co-firing of coal and biomass fuel blends. Progress in Energy and Combustion Science 2001;27(2):171-214.
[148] Williams A, Pourkashanian M, Jones JM. Combustion of pulverised coal and biomass. Progress in Energy and Combustion Science 2001;27(6):587-610.

[149] Bernabei M, Bocchinfuso G, Carrozzo P, De Angelis C. Determination of phenolic antioxidants in aviation jet fuel. In: Proceedings of the 23rd international symposium on high performance liquid phase separations and related techniques. Granada: Spain; 1999.

[150] Christensen ED, Chupka GM, Luecke J, Smurthwaite T, Alleman TL, Iisa K, et al. Analysis of oxygenated compounds in hydrotreated biomass fast pyrolysis oil distillate fractions. Energy and Fuels 2011;25(11):5462-71.

[151] Shonnard DR, Williams L, Kalnes TN. Camelina-derived jet fuel and diesel: sustainable advanced biofuels. Environmental Progress and Sustainable Energy 2010;29(3):382-92.

[152] Bezergianni S, Kalogianni A, Vasalos IA. Hydrocracking of vacuum gas oilvegetable oil mixtures for biofuels production. Bioresource Technology 2009; 100(12):3036-42.

[153] Johnson MB, Wen ZY. Production of biodiesel fuel from the microalga schizochytrium limacinum by direct transesterification of algal biomass. Energy and Fuels 2009;23:5179-83.

[154] Zhuang XS, Yuan ZH, Ma LL, Wu CZ, Xu MZ, Xu JL, et al. Kinetic study of hydrolysis of xylan and agricultural wastes with hot liquid water. Biotechnology Advances 2009;27(5):578-82. 